\title{
Growth and mortality of Conger conger (Linnaeus, 1758) (Pisces Congridae) in the Algerian basin
}

\author{
Mohamed Daoudi '*, Benabdallah Bachir Bouiadjra', Jose Antonio Garcia Charton², Ibrahim El Khalil Beh- \\ mene' \& Farid Hemida ${ }^{3}$ \\ ${ }^{1}$ Laboratory of Sciences and Techniques of Animal Production, Department of Marine Sciences and Aquaculture, \\ Abdelhamid Ibn Badis, Mostaganem, Algeria \\ ${ }^{2}$ University of Murcia, Department of Ecology and Hydrology, Murcia, Spain \\ ${ }^{3}$ National High School of Marine Sciences and Coastal Management (ENSSMAL) BP 19, Dely Ibrahim, Algiers, Algeria \\ ${ }^{*}$ Corresponding author, e-mail: mohamed.daoudi@univ-mosta.dz
}

\begin{abstract}
The growth and mortality of Conger conger (Linnaeus, 1758) (Pisces Congridae) were determined from 295 individuals, ranging from 38.9 to $174 \mathrm{~cm}$ total length, collected in the Algerian basin. The von Bertalanffy growth equation was established on the basis of the analysis of size structures by the ELEFAN I method, and is written as follows: $\mathrm{L}_{\mathrm{t}}=224.4 *\left(1-\mathrm{e}^{-0.2 \mathrm{t}}\right)$. The heightweight relationship shows a higher allometry $\mathrm{Wt}=0.0003 * \mathrm{Lt}^{3.4}$. The total $(\mathrm{Z})$ and natural $(\mathrm{M})$ mortality rates are 1.28 and 0.25 per year respectively. The exploitation rate $\mathrm{E}=80 \%$ seems to show an overexploitation of the $C$. conger stock in the Algerian basin, for which we propose for this situation, management scenarios for this fishery, based on changes in fishing effort and variations in the size of the mesh of the trawl.
\end{abstract}

KEY WORDS Algerian basin; Conger conger; ELEFAN I; growth, mortality; overexploitation.

Received 15.05.2020; accepted 01.10.2020; published online 22.11.2020

\section{INTRODUCTION}

The European conger Conger conger (Linnaeus 1758) (Pisces Congridae) occurs in the North-East Atlantic, from Iceland and Norway to Senegal, but also in the Mediterranean Sea and West of the Black Sea (Froese \& Pauly, 2015).

This species has an elongated subcylindrical body (Fig. 1), compressed behind the anus. The profile of the head is depressed above the eye, which is small with a wide and flattened inter-orbital space. The muzzle is slightly prominent with an oral commissure in the posterior half of the eye. Both jaws are armed with an outer row of very compressed and tight incisiform teeth. The dorsal and anal fins meet the caudal, with segmented rays. The dorsal fin begins above the tip of the pectoral fins (Fischer et al., 1987).

The European conger is a marine benthic species and is caught on rocky and sandy bottoms with a very wide bathymetric distribution, ranging from $40 \mathrm{~m}$ to $800 \mathrm{~m}$ deep (Dieuzeide et al., 1959; Fischer et al., 1987; Quéro \& Vayne, 1997; Wood, 2011). They stay close to the coast when they are young and move to deeper waters as adults.

The European conger reaches sexual maturity at the age of 5-15 years (Fischer et al., 1987), and will reproduce in open water over the deep sea where each individual lays several thousand eggs (Quéro \& Porché, 2005; Correia et al., 2011; Wood, 2011). It takes $2-3$ years for the young people to return to the coastal habitat. 
It is a very voracious carnivorous species. It feeds mainly at night, and its diet consists mainly of bottom-dwelling fish, crustaceans and cephalopods (Fischer et al., 1987).

The European conger eel is fished by beach seines, trawls, gillnets, bottom longlines, traps and handlines. The species is regularly present on Mediterranean markets (Fischer et al., 1987).

This species is a valuable species in the Algerian market, in which it is regularly present and is exploited both by commercial and recreational fishing, and caught by several fishing gears, mainly bottom trawls, hooks and longlines (Correia et al., 2011). Thus, it represents one of the species most caught by recreational fishing in Algeria (Sahi \& Bouaicha, 2003). This seems to show a trend towards overexploitation of the stock. However, the

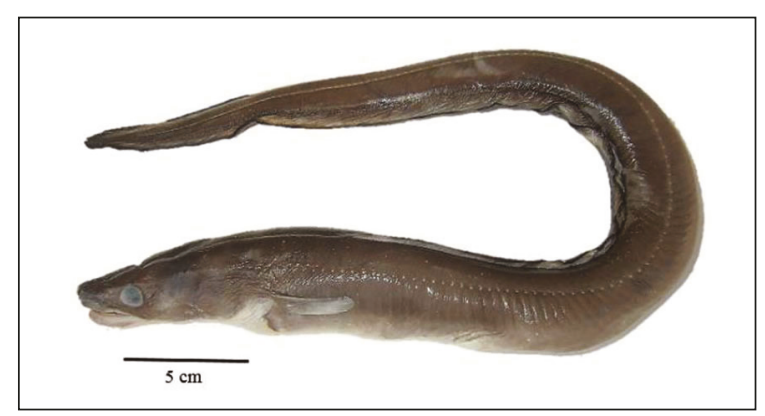

Figure 1. Conger conger (Linnaeus, 1758) species is still not well known, and to our knowledge, no studies on the growth of $C$. conger in the Algerian basin have been published.

In this context, we are interested in the study of this species by estimating these growth and exploitation parameters.

\section{MATERIAL AND METHODS}

\section{Data source}

Sampling was carried out during the period from May 2014 to June 2015 from trips to the Algiers fish market, the ports of Bouharoun, Cherchell, Cap Djinet, Oran, Beni Saf, Mostaganem and the Fouka fishing shelter.

These outings made it possible to collect height and weight data from 295 individuals from C. conger, who come from the different regions of the Algerian basin (Fig. 2).

\section{Study methods}

Growth parameters were estimated from size frequency distributions using indirect numerical methods. Either by converting these distributions into age composition by graphical methods such as the Bhattacharya method (1967) or computerized

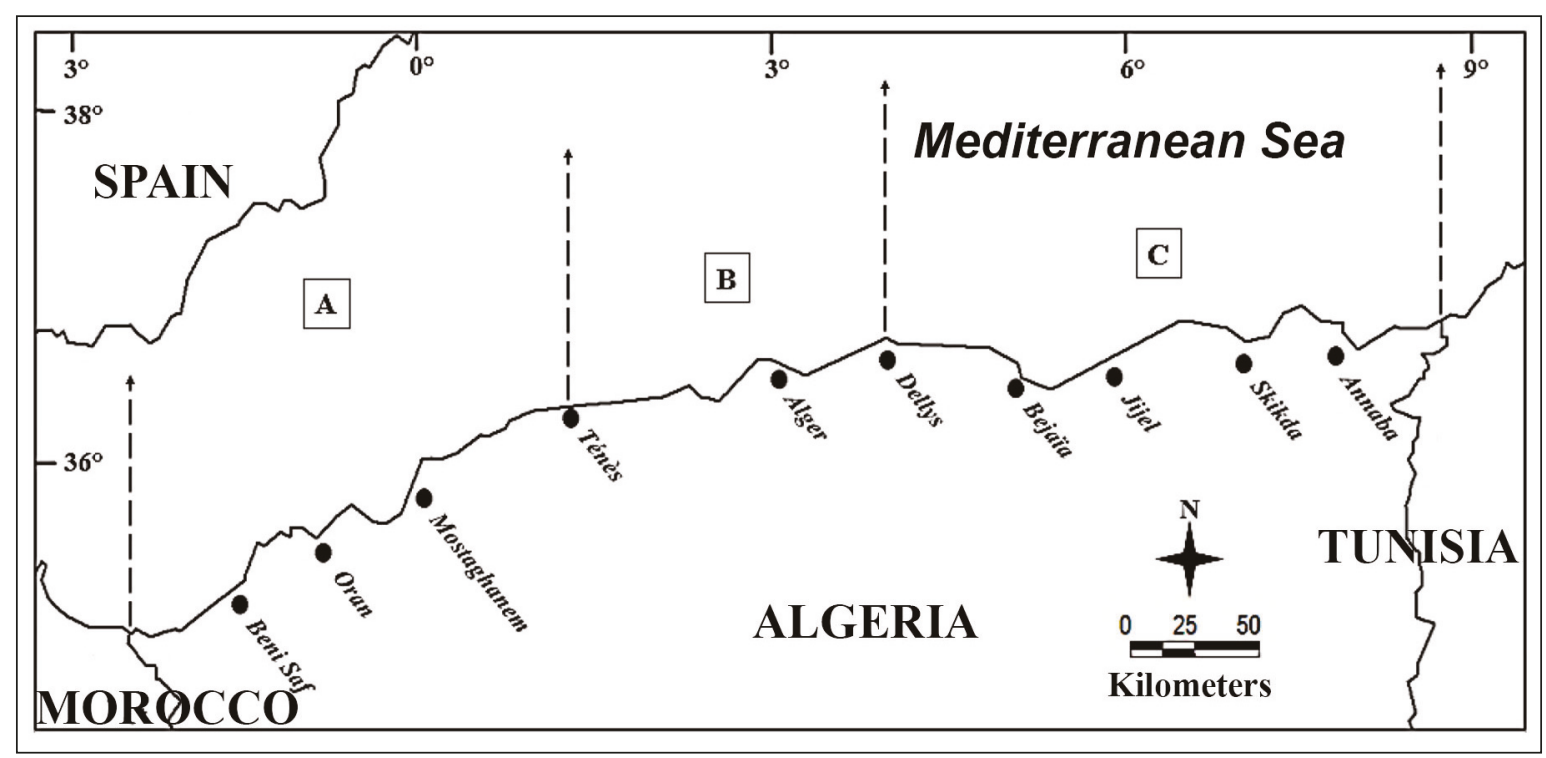

Figure 2. Map of the Algerian Basin (A: Western Region, B: Central Region, C: Eastern Region). 
methods such as the NORMSEP program or directly by analyzing these size structures using the ELEFAN I (Electronic Length Frequency Analysis) software (Sparre \& Venema, 1996), which includes two main steps (Sparre \& Venema, 1996; Pauly \& Moreau, 1997): Step 1: restructuring the length frequencies; Step 2: adjusting a growth curve.

The age-length key obtained by the NORMSEP software is used to estimate growth parameters $(\mathrm{L} \infty$, $\mathrm{K}$ and $\mathrm{t} 0$ ) using FISAT II software using the Tomlinson \& Abramson (1961; Hemida, 2005) method based on least square type adjustment. This method estimates the parameters in such a way that the sum of the squares of the differences between the model and the observations is minimal.

It should be noted that FISAT II software gives by default $\mathrm{t} 0=0$, for this purpose, this parameter is estimated by the Pauly equation (1983) using the formula:

$$
\log _{10}\left(-t_{0}\right)=-0.3922-0.2752 * \log _{10} L_{\infty}-1.038 * \log _{10} K
$$

It is often useful to be able to accurately assess the weight of a fish knowing its size. To do this, there is a simple relationship that links length to mass, and is written as (Sparre \& Venema, 1996):

$$
\mathrm{W}=\mathbf{a} * \mathrm{~L}^{\mathrm{b}}
$$

W: body weight of the fish; L: total length; a and $\mathrm{b}$ are constants, of which $\mathrm{b}$ : represents an allometric coefficient, and when: $\mathrm{b}<3$ : minor allometry; $\mathrm{b}=$ 3: isometry; $\mathrm{b}>3$ : major allometry.

However, the type of allometry is confirmed by the t-test (Schwartz, 1992), based on the comparison of a calculated slope $(\mathrm{P} 0=\mathrm{b})$ with a theoretical slope $(\mathrm{P}=3)$ :

$$
t=\frac{\left|P_{0}-P\right|}{S P_{0}}
$$

If $\mathrm{t}<1.96$ : the difference is not significant; if $t \geq 1.96$ : the difference is significant.

The value of $\mathrm{W}_{\infty}$ is obtained from the equation:

$$
\mathrm{W}_{\infty}=\mathrm{a} \mathrm{L}_{\infty}^{\mathrm{b}}
$$

Where: $a$ and $b$ are those of the height-weight relationship.

The natural mortality rate $\mathrm{M}$ was estimated from the empirical equation of Djabali et al. (1994), which was established on the basis of the growth and mortality parameters of 56 live fish stocks in the Mediterranean:

$\log _{10} M=0.0278-0.1172 \log _{10} L_{\infty}+0.5092 \log _{10} K$

Total mortality is estimated by Pauly (1984) method, using FISAT II software (Gayanilo et al., 2005), from size frequency distributions and growth parameters $\mathrm{K}$ and $\mathrm{L} \infty$. Knowing $\mathrm{Z}$ and $\mathrm{M}, \mathrm{F}$ can be deduced from the equation: $\mathrm{Z}=\mathrm{M}+\mathrm{F}$.

The analysis of the state of the stock can be carried out by calculating the exploitation rate (E) which provides information on the importance of fishing pressure using the following equation (Moreau et al., 1995):

$$
E=\frac{F}{M+F}
$$

When $\mathrm{E}$ is greater than $50 \%$, this implies biological overexploitation.

\section{RESULTS AND DISCUSSION}

\section{Growth parameters}

The size data of 295 specimens of $C$. conger, vary between a minimum of $38.9 \mathrm{~cm}$ and a maximum of $174 \mathrm{~cm}$. These data were grouped into a size frequency distribution table with a $10 \mathrm{~cm} \mathrm{step}$ (Table 1).

The age-length key obtained by the Bhattacharya decomposition method was adjusted by the NORMSEP program (FISAT II), by successive iterations (Table 2, Fig. 3).

The age of the conger (C. conger) obtained from the decomposition of size frequency distributions varies between 1 and 3 years, which is not the case for previous studies. Correia et al. (2009) grouped the age of the European conger between 2 and 12 years from the reading of otoliths. The latter result is similar to those of previous studies (Sbaihi et al., 2001; Correia et al., 2009).

This difference is mainly due to the methods used to determine age and the study area where the sample is taken.

From the age-length key obtained, the growth rate between age group 1 and 2 is about 17.88 $\mathrm{cm} /$ year, and about $33.1 \mathrm{~cm} /$ year between age group 2 and 3 . This is not in line with the von Bertalanffy growth curve since the growth rate be- 


\begin{tabular}{|c|c|c|}
\hline Classes $(\mathrm{cm})$ & Classroom centres $(\mathrm{cm})$ & Effective \\
\hline $38-48$ & 43 & 66 \\
\hline $48-58$ & 53 & 73 \\
\hline $58-68$ & 63 & 62 \\
\hline $68-78$ & 73 & 40 \\
\hline $78-88$ & 83 & 21 \\
\hline $88-98$ & 93 & 13 \\
\hline $98-108$ & 103 & 6 \\
\hline $108-118$ & 113 & 5 \\
\hline $118-128$ & 123 & 3 \\
\hline $128-138$ & 133 & 3 \\
\hline $138-148$ & 143 & 1 \\
\hline $148-158$ & 153 & 1 \\
\hline $158-168$ & 163 & 0 \\
\hline \multirow[t]{2}{*}{$168-178$} & 173 & 1 \\
\hline & $\sum$ & 295 \\
\hline
\end{tabular}

Table 1. Distribution of Conger conger size frequencies (2014-2015 data).

\begin{tabular}{|c|c|c|c|}
\hline Age & 1 & 2 & 3 \\
\hline L moy & 47.38 & 65.26 & 98.36 \\
\hline rate of growth & 17.88 & 33.1 & \\
\hline
\end{tabular}

Table 2. Age-length key of Conger conger adjusted by the NORMSEP program.

tween age group 2 and 3 is expected to be lower than between age group 1 and 2. Thus, for the interpretation to be consistent with von Bertalanffy's model, it is assumed that there is an additional age group between age group 2 and 3 , by assigning an additional year to age group 3 . The plausible expla- nation would be that the peaks corresponding to age groups 2 and 3 are represented by a large number of cohort members, while the cohort represented by the length classes between these two peaks comes from a small age group (Sparre \& Venema, 1996). Similarly, length classes greater than the peak assigned to age group 3 are all grouped together in the latter. This could be explained by the small number of large individuals in our sample.

The Tomlinson \& Abramson (1961) method provides a value of $L \infty$ in the order of $147.43 \mathrm{~cm}$ which corresponds to a value of $\mathrm{K}$ in the order of 0.34 /year. This asymptotic length is less than the maximum observed value $(\operatorname{Lmax}=174 \mathrm{~cm})$, which reflects an underestimation of $\mathrm{L} \infty$. This can be explained by the small number of people assigned to the large individuals in the sample.

The Powell-Wetherall method (Sparre \& Venema, 1996) (Fig. 4) provides a $\mathrm{L} \infty$ of the order of $226.96 \mathrm{~cm}$. This $\mathrm{L} \infty$ value is incorporated into the K-Scan Label of the ELEFAN I program (Fig. 5) to estimate a corresponding $\mathrm{K}$ value based on the highest Rn score (ESP/ASP) (Gayanilo et al., 2005). The program provides a value of $\mathrm{K}=0.5 /$ year. However, this growth coefficient seems to be overestimated for the growth of a benthic species.

In the "Response Surface" subprogram of ELEFAN I (Fig. 6), the value pair $\mathrm{L} \infty=224.4 \mathrm{~cm}$ and $\mathrm{K}=0.2$ year- 1 seems the most appropriate, since the estimated L $\infty$ value is higher than the Taylor approximation $(\operatorname{Lmax} / 0.95=183.16 \mathrm{~cm})$ and very close to the asymptotic length estimated by the Powell-Wetherall method which is suggested by Pauly \& Moreau (1997) for a good estimate of $\mathrm{L} \infty$. Thus, the value of $\mathrm{K}=0.2 /$ year seems to be the most suitable for the growth of a benthic species, which allows us to retain these parameters for the rest of the study.

Table 3 summarizes the growth parameters obtained by the different methods used for $C$. conger (the parameters selected $\mathrm{L} \infty$ and $\mathrm{K}$ are shown in bold).

The linear growth of $C$. conger obtained by the ELEFAN I method is expressed by the relationship:

$$
\mathrm{L}_{\mathrm{t}}=224.4 *\left(1-\mathrm{e}^{-0.2 * \mathrm{t}}\right)
$$

Nevertheless, there is little information on the growth of the European conger eel, not only in the Mediterranean Sea, but also in the different regions 


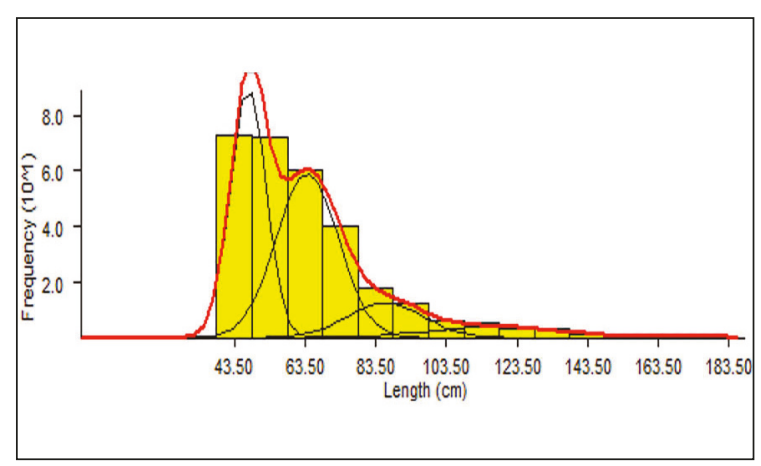

Figure 3. Adjustment of sub-populations obtained by the Bhattacharya method by the NORMSEP program.

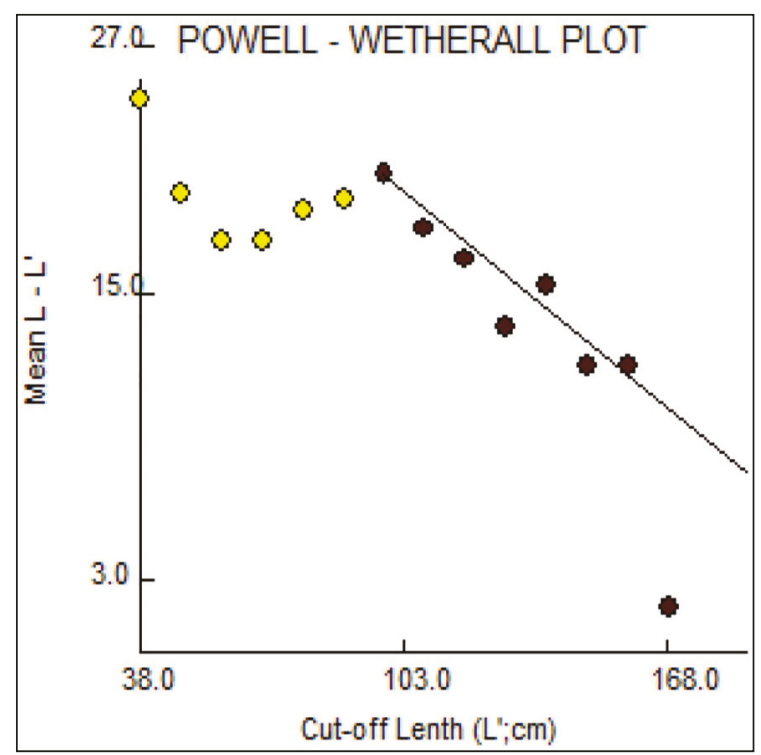

Figure 4. Determination of $L \infty$ and $\mathrm{Z} / \mathrm{K}$ by the Powell-Wetherall method.

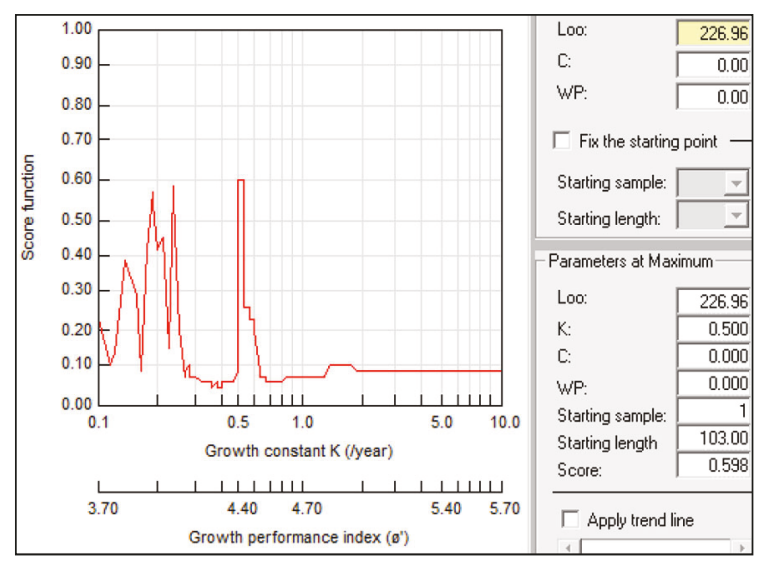

Figure 5. Variation of Rn as a function of K (K-Scan label). of the globe, which makes the comparison of our results very limited.

We find that the asymptotic length estimated in this study is close to the results obtained by O'Sullivan et al. (2003), and Flores-Hernandez (1990) (Table 4), while the value of $\mathrm{K}$ is overestimated compared to the values obtained in the above studies. This may be due to the different methods used and the regions from which samples were taken. The difference between the different study regions is probably related to environmental conditions such as: food availability and water temperature (Overholtz, 1989; Jorgensen, 1992; Brander, 1995; Lorenzen \& Enberg, 2002; Daufresne et al., 2009; Hunter et al., 2016).

\section{Height-weight relationship}

The height-weight relationship was performed from 183 individuals and allows us to calculate the asymptotic weight $(\mathrm{W} \infty)$ of our species.

The results are grouped in Table 5 and figure 7.

The reduced deviation test (Schwartz, 1992) shows a significant difference between the observed allometry coefficient $(b=3.4)$ and the theoretical value $(\mathrm{b} 0=3)$. This exposes a major allometry in C. conger, indicating that the weight grows faster than the length cube. However, the lack of bibliographic data on the height-weight relationship of $C$. conger makes it difficult to compare our results with the literature.

\section{Exploitation indices}

With a high regression coefficient $\left(\mathrm{r}^{2}=0.98\right)$, and eliminating the last two classes of regression, for the following reasons: a) low sample sizes; b) as we approach $\mathrm{L} \infty$ the relationship between age $\mathrm{t}(\mathrm{L})$ and length (L) becomes uncertain (Sparre \& Venema, 1996), the total mortality $\mathrm{Z}$ of $C$. conger is about 1.28/year (Fig. 8).

The natural mortality rate $\mathrm{M}$, estimated by the Djabali et al. (1994), is about 0.25 year $^{-1}$.

The fishing mortality rate on the stock of $C$. conger in the Algerian basin is deduced by the formula. The values of the different mortality rates are shown in Table 6.

The exploitation indices calculated for C. conger in the Algerian basin show that the current exploitation rate is around $80 \%$, which is well above 


\begin{tabular}{|c|c|c|c|c|c|c|c|c|c|c|}
\hline \multirow{2}{*}{$\begin{array}{c}\text { Lmax obs } \\
(\mathrm{cm})\end{array}$} & \multirow{2}{*}{$\begin{array}{c}\mathrm{Lmax} / 0.95 \\
(\mathrm{~cm})\end{array}$} & \multicolumn{3}{|c|}{ Tomlinson and } & \multirow{2}{*}{\multicolumn{2}{|c|}{ Powell Wetheral }} & \multicolumn{4}{|c|}{ ELEFAN I } \\
\hline & & \multicolumn{3}{|c|}{ Abramson } & & & \multicolumn{2}{|c|}{ K-Scan } & \multicolumn{2}{|c|}{ Response Surface } \\
\hline \multirow{2}{*}{174} & \multirow{2}{*}{183.16} & $\mathrm{~L} \infty$ & $\mathrm{K}$ & to & $\mathrm{L} \infty$ & $\mathrm{Z} / \mathrm{K}$ & $\mathrm{L} \infty$ & $\mathrm{K}$ & $\mathrm{L} \infty$ & $\mathrm{K}$ \\
\hline & & 147.43 & 0.34 & -0.31 & 226.96 & 4.64 & 226.96 & 0.5 & 224.4 & 0.2 \\
\hline
\end{tabular}

Table 3. Summary of estimated growth parameters for Conger conger.

\begin{tabular}{|c|c|c|c|c|c|c|c|c|}
\hline Author & Country & Region & Methodology & $\mathrm{L} \infty$ & $\mathrm{K}$ & T0 & Gender & $\mathrm{W} \infty$ \\
\hline $\begin{array}{l}\text { O'Sullivan } \\
\text { et al., } 2003\end{array}$ & Ireland & $\begin{array}{l}\text { Irish coastal } \\
\text { waters }\end{array}$ & $\begin{array}{l}\text { Reading } \\
\text { Otoliths }\end{array}$ & 271 & 0.037 & -1.396 & / & \\
\hline $\begin{array}{l}\text { O'Sullivan } \\
\text { et al., } 2003\end{array}$ & Ireland & $\begin{array}{l}\text { Irish coastal } \\
\text { waters }\end{array}$ & $\begin{array}{l}\text { Reading } \\
\text { Vertebrae }\end{array}$ & 214 & 0.059 & -1.96 & / & \\
\hline $\begin{array}{l}\text { Correia et al., } \\
2009\end{array}$ & Portugal & $\begin{array}{l}\text { Atlantic Iberian } \\
\text { waters }\end{array}$ & $\begin{array}{l}\text { Reading } \\
\text { Otoliths }\end{array}$ & 265 & 0.07 & -1.20 & $\mathrm{~F}$ & \\
\hline $\begin{array}{l}\text { Flores- } \\
\text { Hernandez, } \\
1990\end{array}$ & France & $\begin{array}{l}\text { Mor Braz, } \\
\text { South Brittany }\end{array}$ & $\begin{array}{l}\text { Reading } \\
\text { Otoliths }\end{array}$ & 94.8 & 0.27 & -0.79 & M & 1.6 \\
\hline $\begin{array}{l}\text { Flores- } \\
\text { Hernandez, } \\
1990\end{array}$ & France & $\begin{array}{l}\text { Mor Braz, } \\
\text { South Brittany }\end{array}$ & $\begin{array}{l}\text { Reading } \\
\text { Otoliths }\end{array}$ & 229 & 0.068 & -2.4 & $\mathrm{~F}$ & 30.4 \\
\hline $\begin{array}{l}\text { Fannon et al., } \\
1990\end{array}$ & Ireland & $\begin{array}{l}\text { Small Saltee } \\
\text { Island, Wexford } \\
\text { County }\end{array}$ & $\begin{array}{l}\text { Reading } \\
\text { Otoliths }\end{array}$ & 265 & 0.063 & -0.39 & $\mathrm{~F}$ & - \\
\hline
\end{tabular}

Table 4. Growth parameters of Conger conger according to the literature.

\begin{tabular}{|c|c|c|c|c|c|}
\hline Species & $\mathrm{a}$ & $\mathrm{b}$ & $\mathrm{R}^{2}$ & $\mathrm{t}$ & $\mathrm{W} \infty(\mathrm{kg})$ \\
\hline Conger conger & 0.0003 & 3.399 & 0.96 & 7.82 & 27.84 \\
\hline
\end{tabular}

Table 5. Parameters of the height-weight relationship.

\begin{tabular}{|l|c|c|c|c|}
\hline Species & $\mathrm{M}\left(\right.$ year $\left.^{-1}\right)$ & $\mathrm{Z}\left(\right.$ year $\left.^{-1}\right)$ & $\mathrm{F}\left(\right.$ year $\left.^{-1}\right)$ & $\mathrm{E}(\%)$ \\
\hline C. conger & 0.25 & 1.28 & 1.03 & 80 \\
\hline
\end{tabular}

Table 6. Exploitation indices of Conger conger. equilibrium (50\%), which implies a condition of biological overexploitation of the European conger stock in the Algerian basin. On the basis of these results, and in the context of sustainable fisheries management, we suggest reducing the pressure on the European conger eel stock through both trawl fishing and recreational fishing, while reducing fishing effort, directing fishermen to other fishing grounds and/or increasing the mesh size of trawls used to fish the stock in question.

Nevertheless, a study of the state of exploitation using appropriate models is essential in order to confirm these results, to verify the proposed development scenarios and to evaluate their impacts on the level of exploitation of the European conger eel. 


\begin{tabular}{|c|c|c|c|c|c|c|c|}
\hline \multirow{3}{*}{\multicolumn{4}{|c|}{$\begin{array}{l}\text { Enter the lower and upper limit of any two } \\
\text { parameters. To make a parameter constant, } \\
\text { enter the same value for lower and upper } \\
\text { limit. } \\
\text { - Statting Point }\end{array}$}} & \multirow{5}{*}{$\begin{array}{l}\text { Parameters } \\
\text { Loo: } \\
\mathrm{K}: \\
\mathrm{C}: \\
\text { WP: }\end{array}$} & From & \multicolumn{2}{|c|}{ To } \\
\hline & & & & & 174 & \multicolumn{2}{|r|}{300} \\
\hline & & & & & 0.2 & \multicolumn{2}{|r|}{0.8} \\
\hline \multicolumn{3}{|c|}{ Starting sample: $1 \quad$} & & & 0.00 & \multicolumn{2}{|r|}{0.00} \\
\hline \multicolumn{4}{|c|}{ Starting length: $103.0 \mathrm{\square}$} & & 0.00 & \multicolumn{2}{|r|}{0.00} \\
\hline \multicolumn{8}{|c|}{ cores: ELEFAN I Method } \\
\hline KILoo & 199.20 & 205.50 & 211.80 & 218.10 & 224.40 & 230.70 & 237.00 \\
\hline 0.20 & 0.044 & 0.154 & 0.506 & 0.484 & 0.484 & 0.354 & 0.155 \\
\hline 0.23 & 0.487 & 0.484 & 0.506 & 0.155 & 0.135 & 0.124 & 0.098 \\
\hline 0.26 & 0.194 & 0.155 & 0.100 & 0.093 & 0.107 & 0.120 & 0.120 \\
\hline 0.29 & 0.132 & 0.098 & 0.107 & 0.107 & 0.160 & 0.154 & 0.176 \\
\hline 0.32 & 0.107 & 0.107 & 0.183 & 0.153 & 0.176 & 0.176 & 0.164 \\
\hline 0.35 & 0.143 & 0.176 & 0.175 & 0.176 & 0.164 & 0.150 & 0.165 \\
\hline 0.38 & 0.176 & 0.175 & 0.164 & 0.164 & 0.189 & 0.165 & 0.165 \\
\hline 0.41 & 0.200 & 0.164 & 0.158 & 0.189 & 0.165 & 0.216 & 0.230 \\
\hline 0.44 & 0.143 & 0.207 & 0.189 & 0.216 & 0.202 & 0.264 & 0.264 \\
\hline 0.47 & 0.207 & 0.189 & 0.202 & 0.202 & 0.264 & 0.264 & 0.598 \\
\hline
\end{tabular}

Figure 6. $\mathrm{K} / \mathrm{L} \infty$ torques and their respective scores (Rn) (ELEFAN I) of Conger conger.

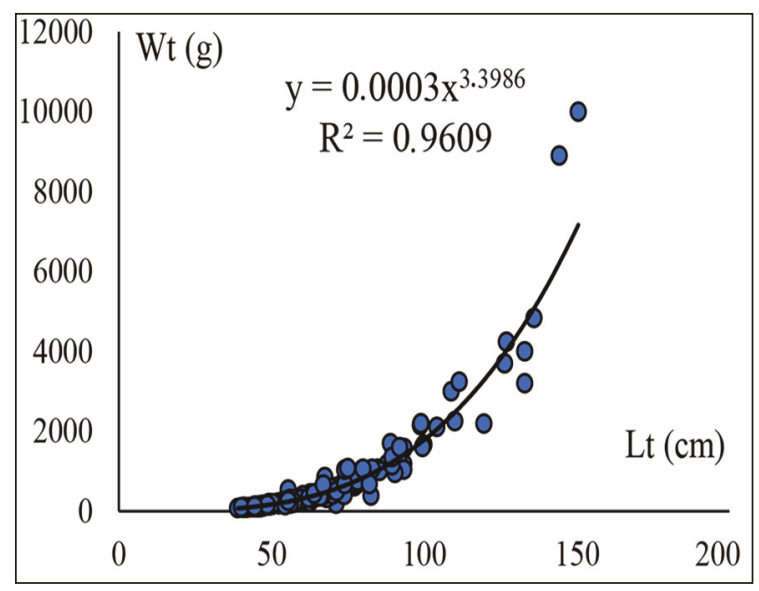

Figure 7. Size and weight ratio of Conger conger .

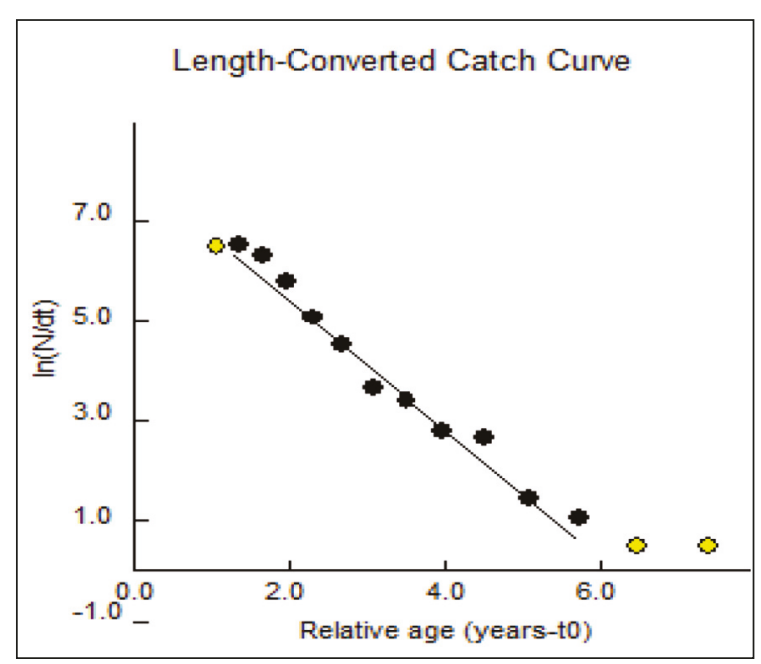

Figure 8. Linearized catch curve.

\section{CONCLUSIONS}

The study of the growth of $C$. conger in the Algerian basin was carried out by analysing age structures and size structures. The growth parameters used are those obtained by the ELEFAN I method, carried out using FISAT II software, by presenting the following linear von Bertalanffy growth formula:

$$
\mathrm{L}_{\mathrm{t}}=224.4 *\left(1-\mathrm{e}^{-0.2 * \mathrm{t}}\right)
$$

Weight growth shows a major allometry in $C$. conger $(b=3.4)$, whose weight grows faster than the cube of the length.

The exploitation rate $\mathrm{E}=80 \%$ shows that the conger eel stock appears to be in a state of organic overexploitation. To remedy this situation, we propose management scenarios for this fishery, based on changes in fishing effort and variations in trawl mesh size, emphasizing the need to estimate the level of exploitation of the species in question by appropriate models using the parameters estimated in this study.

This shows that the study of growth is a key step in the management of fish stocks and fisheries management, presenting the first step for estimating the level of exploitation of a given species and assessing the state of its stock.

\section{ACKNOWLEDGEMENTS}

The Authors would like to thank the Directorate General of Scientific Research and Technological Development for its accompaniment of the Projects for University Research and Formation.

\section{REFERENCES}

Bhattacharya P.K., 1967. Efficient estimation of a shift parameter from grouped data. Annals of Mathematical Statistcs, 38: 1770-1787.

Brander K.M., 1995. The effect of temperature on the growth of Atlantic cod (Gadus morhua L.). ICES Journal of Marine Science, 52: 1-10.

Correia A.T., Manso S. \& Coimbra J., 2009. Age, growth and reproductive biology of the European conger eel (Conger conger) from the Atlantic Iberian waters. Fisheries Research, 99: 196-202. https://doi.org/10. 1016/j.fishres.2009.06.002 
Correia A.T., Barros F. \& Sial A.N., 2011. Stock discrimination of European Conger eel (Conger conger L.) using otolith stable isotope ratios. Fisheries Research, 108: 88-94. https://doi.org/10.1016/j.fishres.2010. 12.002

Daufresne M., Lengfellner K. \& Sommer U., 2009. Global warming benefits the small in aquatic ecosystems. Proceedings of the National Academy of Sciences of the United States of America, 106: 12788-12793. https://doi.org/10.1073/pnas.0902080 106.

Djabali F., Mehailia A. \& Koudil M. \& Brahmi B., 1994. A Reassessment of Equations for Predicting Natural Mortality in Mediterranean Teleosts. NAGA, The ICLARM Quarterly: 33-34.

Dieuzeide R., Novella M. \& Roland J., 1959. Catalogue des poissons des côtes algériennes. Tome II: Osteopterygiens. Bulletin des travaux publiés par la Station d'aquiculture et de pêche de Castiglione, 299 pp.

Fischer W., Bauchot M.L. \& Schneider M., 1987. Fiches FAO d'identification des espèces pour les besoins de la pêche (révision 1). Méditerranée et Mer Noire. Zone de pêche 37. FAO (éd), Vol. I: Invertébrés: 1760 et Vol. II : Vertébrés: 760-1530.

Flores-Hernandez D., 1990. Conger fishing (Conger conger L.) in Mor Braz, South Brittany. (Elements of biology and resource management). Doctoral thesis, Aix Marseille II, France, 150 pp.

Froese R. \& Pauly D., 2015. FishBase. World Wide Web electronic publication. Editors. www.Fishbase.org, version 2015.

Gayanilo J.F.C., Sparre P. \& Pauly D., 2005. FAOICLARM Outils d'évaluation des stocks II (version révisée) Guide d'utilisation.

Hemida F., 2005. Les sélaciens de la côte algérienne: Biosystématique des requins et des raies, écologie, reproduction et exploitation de quelque populations capturées. [The selachians of the Algerian coast: Biosystematics of sharks and rays; ecology, reproduction and exploitation of some captured populations]. Thèse de doctorat d'état, USTHB, Alger, 231 pp.

Hunter A., Speirs DC. \& Heath MR., 2016. Investigating trends in the growth of five demersal fish species from the Firth of Clyde and the wider western shelf of Scotland. Fisheries Research, 177: 71-81. https:// doi.org/10.1016/j.fishres.2016.01.005

Jorgensen T., 1992. Long-term changes in growth of North-east Arctic cod (Gadus morhua) and some environmental influences. ICES Journal of Marine Science, 49: 263-277.

Lorenzen K. \& Enberg K., 2002. Density-dependent growth as a key mechanism in the regulation of fish populations: evidence from among-population comparisons. Proceedings of the Real Society London B., 269: 49-54.

Moreau J., Palomares M.L.D., Torres J.R.F.S.B. \& Pauly D., 1995. Atlas démographique des populations de poissons d'eau douce d'Afrique. [Demographic atlas of freshwater fish populations in Africa]. ICLARM Rapport Technologies, 45, 140 pp.

O’Sullivan S., Moriarty C., Fitzgerald R.D., Davenport J. \& Mulcahy M.F., 2003. Age, growth and reproductive status of the European conger eel, Conger conger (L.) in Irish coastal waters. Fisheries Research, 64: 55-69.

Overholtz W.J., 1989. Density-dependent growth in the Northwest Atlantic stock of Atlantic mackerel (Scomber scombrus). Journal of Northwest Atlantic Fishery Science, 9: 115-121.

Pauly D., 1983. Some simple methods for the assessment of tropical fish stocks. FAO Fish. Tech. Pap., (234): $52 \mathrm{pp}$.

Pauly D., 1984. Fish population dynamics in tropical waters: a manual for use with programmable calculators. ICLARM. N ${ }^{\circ}$ 143. Manila, Philippines, $325 \mathrm{pp}$.

Pauly D. \& Moreau J., 1997. Méthodes pour l'évaluation des ressources halieutiques. Collection Polytech. (Ed.) Cépaduès. INP, Toulouse, 288 pp.

Quéro J.C. \& Porché P., 2005. Les poissons de mer. Jean Paul Gisserot (éd.), France, 32 pp.

Quéro J.C. \& Vayne JJ., 1997. Les poissons de mer des pêches françaises. Encyclopédies. Delachaux et Niestlé (éd), Paris, 304 pp.

Sahi MA. \& Bouaicha M., 2003. La pêche artisanale en Algérie. Doc. FAO Copemed, 19 pp.

Sbaihi M., Fouchereau-Peron M., Meunier F., Elie P., Mayer I., Burzawa-Gerard E et al. 2001. Reproductive biology of conger eel from the south coast of Brittany, France and comparison with the European eel. Journal of Fish Biology, 59: 302-318.

Schwartz D., 1992. Méthodes statistiques à l'usage des médecins et des biologistes. Flammarion Ed., 3ème ed., 15 ème tirage, $306 \mathrm{pp}$.

Sparre P. \& Venema S.C., 1996. Introduction à l'évaluation des stocks de poissons tropicaux. Première partie: manuel, Deuxième partie: exercices. FAO document technique sur les pêches, rev. 1. Rome, 306/1: 401 pp. 306/2: 94 pp.

Tomlinson P.K. \& Abramson N.J., 1961. Fitting a von Bertalanffy growth curve by the least squares. California Fish and Game Fish Bulletin, 116: 1-69.

Wood L., 2011. Faune et Flore Sous-marines de la Méditerranée: Identifier facilement 289 espèces. Delachaux et Niestlé, Paris, 128 pp. 